DOI https://doi.org/10.36059/978-966-397-208-4/109-127

\title{
SPECIFICITIES OF MAKING MANAGEMENT DECISIONS IN THE SOCIAL SYSTEM AT THE URBAN COMMUNITY LEVEL
}

\author{
Gorban G. O.
}

\section{INTRODUCTION}

Today, Ukraine is actively implementing self-managment in all spheres of public life. The development of civil society, creation of non-governmental organisations, formation of territorial communities, and their unification make it necessary to determine the specifics of managing social systems that do not have a clear subordination and interaction hierarchy. Manager's professsionalism is the crucial importance in the ability to guarantee effective management and decision-making in new formats of such interaction. That is, the formation of a certain integral organization of manager's professional and personal characteristics, which causes the formation of their professionally significant qualities, which are manifested in the creative realization of professional activity during the lifetime. The specificity of the manager's professionalism is that in making the decision they perform complex systematic actions, which are their own intellectual actions related to the processes of self-awareness; mental actions on the levels of "matter problem"; procedural actions "management - administrating - organization"; social actions in the parallel "strategic (actions towards low-level managers) tactical (actions given by top-level managers)".

In the context of management activities and decision-making processes, there are two main tasks that require more detailed research: 1) determining the specificities of decision-making in social systems of various forms of organization (formal, informal, self-organized); 2) distinguishing the specificities of the professional training of managers in higher education institutions and the system of retraining to work in the current conditions of global transformation. Within the scope of solving the first problem, it is necessary to determine the specificities of decision making both in formally organized systems and in informally and selforganized systems. Regarding formally organized systems with their clear structure and hierarchy, a considerable amount of research can be noted regarding the analysis of the specifics of management decisions. The specificities of decision making in informally organized and self-organized systems are less explored. In our research, we need to distinguish the socio-psychological specificities of the processes that lead to the making and implementation of management decisions in such systems. 
The present time characterized by high transiency, stable instability and high level of uncertainty, requires the development of effective technologies for training managers due to these conditions, both at the level of higher education institutions and further education of highly qualified specialists in a specific industrial sphere for management activities. Here we have to take into account the two-tier social systems management, which determines its specific feature: the necessity to take into account every time the decision of the lower-order systems towards self-organization and self-development, that is, the subject of the management object. It is in this direction that we will search for a solution to the second problem.

\section{Analysis of the specificities of decision-making in social systems at the urban community level}

The complexity of managing an urban community is conditioned to the fact that this deliberate action must convert a complex social system from one actually existing state to another (given). What is important here is the need to carry out certain external actions aimed at changing the trajectory of the natural movement of this system and coordinating the cooparation of all its social institutions, ensuring the comfortable social existence of people in the community. But social systems are characterized by some conservatism, which impedes the changes that take place in them. The presence of the human in social system makes this resistance poorly predictable, and therefore difficult to predict and take into account during management. In addition, it should be noted that the urban community, as a social system, is characterized by a large quantity and complexity of elements and links between them, high dynamism, the existence of non-functional links between elements, action of different factors ${ }^{1}$. Therefore, the processes that occur in these systems are poorly formalized and require detailed design, professional expertise, thorough forecasting, and cooperation by rules that allow harmonizing the interests of social system actors and giving solidarity to management and its results.

Within the various forms of social system organizations, it is possible to identify individual structural elements of the management system, which determine the orientation of the analysis of these systems. Individual researchers add to the components of the management system, in addition to the most common (subject, object, cooperation as influences), sometimes other elements, namely: content of management (management technologies), social resources, principles and methods of management, purpose of management, management

${ }^{1}$ Швалб Ю.М. Психологічні засади соціогенеза: громада, населення і спільнота як суб'єкти соціальних відносин. Актуальні проблеми психологї : збірник наукових праць. Т. 7. Екологічна психологія, 2014. Вип. 35. С. 317-329. 
activities. Such diversity in defining the elements of a management system is predetermined by the tasks that are solved by individual researchers: analysis of the management system of different nature; research of certain factors; selection of certain elements and concepts from the whole control system.

In order to find out the specific peculiarities of the decision-making process at the urban community level, we conducted an empirical study aimed at defining principles and building models for managing the urban community as a social system ${ }^{2}$.

This goal was achieved through the following main tasks:

- identification of the basic organizational forms of the system in which management is exercised;

- specification of management entity at the urban community level;

- ratio determination of organizational forms of the system and the subjects of management;

- discovery of the main decision-making strategies that are used in the management of the urban community level;

- identification of the models of urban community management as a social system by determining links between organizational forms of the system and decision-making strategies.

Generalization of the obtained results was carried out by a modeling method. Today, modeling is one of the main means of cognition, but it is interpreted differently in the professional literature from particular fields of research. Modeling as a method of cognition was investigated by V. A. Bogdanov, O. O. Bondarev, O. M. Dakhin, V. L. Zlivkov, Z. S. Karpenko, E. V. Luzik, S. D. Maksimenko, V. I. Mikhieiev, K. V. Semashko, I. A. Sheremet et al. Most researchers note that modeling is practically the only valid method of scientific research of systems and processes of any nature in many spheres of human activity. This is due to the fact that this method allows to combine the empirical and theoretical in the study, that is, in the study of a particular object integration of experimentally obtained content with the construction of logical structures and scientific abstractions.

Essential properties of models are: subjectivity (created by the subject of knowledge); dual nature (the model is both a prerequisite and a means of cognition); the ability to transform (the model can be transformed but the original can not); compactness (model reproduces the object in a simplified form); specific informativeness (the model is an abstraction) ${ }^{3}$.

\footnotetext{
${ }^{2}$ Горбань Г.О. Психологія прийняття управлінських рішень у соціальних системах на рівні міської громади : дис. ... д-ра психол. наук : 19.00.05. Київ, 2014. 493 с.

Методы социальной психологии / под общ. ред. Н.С. Минаевой. Москва : Акад. проект ; Екатеринбург : Деловая книга, 2007. 350 с.
} 
The model used in scholarly research must meet the following requirements:

- unambiguously submit (with the necessary depth of detail) relevant objects of study, created by nature or man;

- be an auxiliary natural or artificial object that at some point replaces the original, that is, it is created to obtain information about the original that cannot be directly explored;

- retain such properties of the original as are essential for the study;

- rely on and operate idealized constructs.

Modeling plays a special role in the study of any level of the social system. It provides a concise and structured presentation of information that is not overloaded with minor factors and insignificant characteristics of the original. This method provides an emphasis on those characteristics that are crucial to a particular study of the social system and, therefore, is a way of analysis of the movement direction of the system, predicting its processes, taking corrective and control actions.

The analysis of scientific sources allows us to determine the specific characteristics of modeling as a systematic method of studying a phenomenon or process, namely: identification of significant elements; integrity; possibility of forecasting; informativeness; convenience of analysis; structural properties; adequacy of object reproduction.

An empirical study of the specificities of urban community management as a social system has enabled us to identify the main specificities of decisionmaking in such systems. We have noted that each of the types of social system organization (formal, informal, self-organized), which we have analyzed at the theoretical stage ${ }^{4}$, has its own specific subject of life management of such system at the urban community level.

An analysis of the specificities of social systems management shows that identifying a management entity is a complex and ambiguous process. However, a detailed analysis of the entity that manages (the one who develops, argues and controls the program), and the managed entities is important here. These managed entities directly interact with the management entity, that is, implement management programs by engaging in a particular regulated activity (manufacturing, political, judicial, etc.) to which management is directed. Unlike most of the specificities and characteristics of the regulated field of action, which are fairly objective, more or less

${ }^{4}$ Горбань Г.О. Соціальні системи як об’єкт управління: соціально-психологічний аспект. Актуальні проблеми психологї : Зб. наук. праць Ін-ту психології ім. Г.С. Костюка НАПН України. Т.І : Організаційна психологія. Соціальна психологія. Економічна психологія / за ред.. С.Д. Максименка, Л.М. Карамушки. 2011. Вип. 32. С. 267-272. 
accurately predicted and can be specified in management programs, managed entities have their own specific characteristics that are associated with the self-activity, with the individuality of people, which are part of the management object.

Based on the fact that the main elements of management in the social system are the society itself, social groups, communities, individual, internal and external relations, the subject of management is determined by the level of the social system - from the state to the individual. In our research, when we understand the urban community as a viable social system, the subject of management, and therefore the decision-making subject, researchers also call the residents of the city (collective entity), and individual public organizations, movements, city government, which the city council embodies, and specifically the mayor of the city. We believe that the specification of the management entity is determined by the context and direction of the taken decisions. Therefore, in analyzing the results, it was very important for us to identify the management entity for each type of social system organization (formal, informal, self-organized). According to the research, we have identified the following three groups of management entities that ensure the viability and feasibility of community-based solutions:

1) city authorities;

2) public organizations;

3) reference groups.

Comparison and analysis of the obtained data sets made it possible to prove the correspondence of the type of organization of the social system and the specific subject of life management at the urban community level, namely three pairs according to the relation "form of system organization - the subject of management":

2) formal system - city authorities;

3) informal system - reference groups;

4) self-organized system - public organizations.

Further analysis made it possible to differentiate basic decision-making strategies in social systems at the urban community level and identify their specificities. We have identified three content groups that we believe can be identified as decision-making strategies:

1) a strategy for qualitative changes in the vital activity of the social system;

2) a strategy for improving the existing forms of vital activity of the social system;

3) a strategy for supporting the vital activity of social system.

The strategy of qualitative change is characterized by the project's relevance to human values, the need for self-development, the presence of 
new and non-standard ideas, the forward-looking optimism, and the approximation to the ideal and so on. The strategy of improvement, according to the results of the analysis, is manifested in the desire to find a better balance between the situation and the known actions, to find new forms for the efficiency of the vital activity of the system, to define new development benchmarks, to improve the existing situation. The strategy of vital activity support of the social system is based on the orientation to preserve existing ideas, to ensure compliance with the expectations of the environment, to apply actions within known means and techniques, to comply with existing rules.

The results of generalizing the specificities of decision-making, determining the specificity of social systems and their specificities at the urban community level make it possible to note that decision-making processes significantly depend on the relationship between the form of organization of the social system and the decision-maker in it. Note that to study the decision-making process and build a conceptual model of its analysis, we must systematically consider the specificities:

- the subject of decision making, his/her readiness for professional implementation of this process, namely: goal setting, reflections, expert analysis;

- the integral characteristics of this process: the personal space of the decision-maker, the responsibility of the decision-maker, the consequences prolongation of the decision-maker;

- forms of social system organization at the urban community level: formal, informal, self-organized;

- the overall strategy of this process: qualitative changes, improvements, support.

Thus, according to the results of theoretical and empirical research, we have built models of decision-making, which fixed the specificities of the decision-making process in social systems, taking into account the specificities of the relationship between the form of the urban community organization as a social system and the dominant subject of decision-making: the formal system - city authorities; informal system - public opinion; selforganized - public organizations ${ }^{5}$.

Specificities of decision making at the urban community level in the relation: "formal system - city authorities" are in the presence of an additional chain (executive branch), in which there is a certain transformation of the idea and content of the decision. The City Council (the mayor or a certain group of co-workers) as a decision-maker takes the dicision and sends it to the

\footnotetext{
${ }^{5}$ Горбань Г.О. Психологія прийняття управлінських рішень у соціальних системах на рівні міської громади : Автореф. дис... док. психол. наук: 19.00.05. Київ, 2014. 40 с.
} 
executive branch, which should formulate this decision in the form of specific tasks for the executors. It should be noted that, in accordance with the patterns found in social psychology, such activity is characterized by the recoding and reformatting of information, which usually leads to the loss of some information and certain changes in its content. Such changes occur twice: at the executive branch and executor's level. In fact, we have the implementation of a solution that is only partially consistent with the decision. The analysis of the results also has a certain gap as to the final result. The analysis of the result is performed by the executors according to the interpreted decision. The results of the analysis are the basis for the evaluation and correction of the results and consequences which are carrying out by the authorities in accordance with the decisions made by them (their format of interpretation).

Therefore, executive institutions, as an additional element of decision-making, are a risk zone that causes problem areas to emerge during the information sharing in a holistic decision-making cycle. The relevant formats of socio-psychological ensuring for decision-making processes must play an important role at the point of information sharing. The work of organizational psychologists in government institutions should ensure the organization of quality social communication, which activates perspective reflection and thought communication in order to facilitate a clearer understanding of the decision that has been made, its adequate formulation in the task for the executors.

Specificities of decision making at the urban community level in relation to "informal system - public opinion" reveal the existence of a certain group opinion. This opinion is disseminated in the public communication of informal groups and transformed into more defined (concrete) public opinion. Promoting such an idea at the community level initiates the decision-making process and its implementation by bringing together informal groups.

Here we record the existence of an uncertain situation, which is not perceived within the framework of power, but manifested by informal groups that arise in the community spontaneously. The uncertainty of a situation is formulated in different groups in the form of separate ideas and opinions, which are expressed and discussed among their members. Given that each person is a member of a variety of informal groups, these thoughts and ideas are transmitted to other groups, combined during communication and form a certain social position. Such dissemination of the formulated idea is transformed into public opinion. It is important that in such a scenario, the subject of formulating the need for decision-making is the very community (mass) that self-organizes and initiates decision-making with the willingness to actively implement it in order to achieve a certain result.

Therefore, in the decision-making process in informal systems, society is self-organizing, which enables it to record, initiate and implement decisions. 
Here we can record an active process of public opinion development, which distinguishes the situation of uncertainty and realizes the need for its transformation. The problem areas of such a development of the decisionmaking process, where public opinion is the subject of initiation and decisionmaking, can be attributed to the following:

1) the need for a formal record of the decision;

2) support the vital activity of informal groups that have identified a situation of uncertainty, initiated active communication and influenced decision-making.

Specificities of decision making at the urban community level in the relation "self-organized system - public organizations" are characterized by a certain integration of the first two models. There should be sufficient consolidation of the authorities and society regarding the forecasting of situations of change, which cause uncertainties of further development and require conscious design of the set changes. The decision-making procedure is based on development forecasting of the social system, the organization of its life according to a socially important goal, the conscious design of "from the future". It is public organizations that make it possible to summarize and structure public opinion, to ensure that actions are organized with the city authorities, which have a certain administrative resource.

The management decision-making process in the context of the "self-organized system - public organizations" relation makes it possible to isolate a complex system element that needs additional analysis. These are general social processes of conscious design and goal-setting for community development, which must precede decision-making by predicting situations of uncertainty. A key point in this approach is to advance the design of new community life situations that respond to their future needs. Therefore, the importance of the activities of public organizations is determined by the fact that they can effectively consolidate existing public opinion with the actions of the authorities and defend it. They are able to initiate those "from the future" decisions that meet precisely the needs of society, and facilitate the active implementation of projected actions in the new situation of system development.

According to the research results, the most problematic areas that arise here are:

1) the process of realizing the need to design the system development;

2) the conformity of the authorities' actions with the public opinion that is formed regarding the future;

3 ) the contradiction regarding the content of the value component of the decision-makers' actions.

In our opinion, the decision-making process in a social system at the urban community level can be presented in three types of its implementation, 
depending on the relation between the form of organization of the system and the decision-maker. Each of the simulated types reveals its specific elements, as well as features and problem areas that have a socio-psychological nature:

1) for the relation "formal system - city authorities" we note the problem of information loss during transmitting and analysis of results. The problem is conditioned by the existence of the executive branch as a sufficiently independent element of the transmitting process of the taken decisions;

2) for the relation "informal system - public opinion" the main problem areas are determined by the subject of decision making (public opinion), forms of public communication and self-organization of social groups, as well as actions on fixing, initiating and implementing the decision-making process, which are difficult to predict in the informal social system;

3) for the relation "information system - public organizations" are decisive problems that are related to the awareness of the need for design, the specifics of the vision of the future, conflicts about the content of the value component of the actions of the decision-makers.

We believe that building and defining specific decision-making at the community level gives us the opportunity to build focused professional and psychological training for both management personnel for such social systems and organizational psychologists, ready to cooperate in the context of social and psychological decision-making processes.

\section{Socio-psychological preparation of managers for professional activity}

In the modern world, education is a leading cultural and civilizational factor in ensuring human development and professional development. Improvement of the educational sphere is a perennial, permanent problem. It is constantly in dynamics, always exists as a social, economic and, above all, a psycho-pedagogical problem. After all, the task of the school (above all - higher school) is to ensure the formation of an individual image of a professional $^{6}$.

Today, specialists in various fields are faced with the problem of organizing effective subjective cooparation, and further career development takes it to a new level, namely, management cooparation. Therefore, we are faced with the fact that readiness for subject-subject cooparation is important in the professional activity of specialists of a certain level. Forming this readiness should be a priority in the higher education process, but the percentage of disciplines in psychological

\footnotetext{
${ }^{6}$ Левченко О., Скляр П., Третьяченко В. Соціально-психологічні моделі та механізми професійного становлення майбутніх фахівців у вищій школі : монографія. Луганськ : Видво СНУ ім. В. Даля, 2011. 240 с.
} 
education is kept to a critical minimum. Therefore, the question arises: whether it is possible to talk about a worthy training of a specialist, understanding of the deep processes of professional activity, awareness of the professional specificity of professional cooparation.

Even the most limited interval of activity consists of a series of decisions that a person makes in the process of choosing a particular variant, goals, means of this activity. It can be argued that every decision made is to some extent managerial in its own actions. However, the term management decision is commonly used to define the decisions that managers make in the process of maintaining an organization. Management decisions differ from ordinary decisions because they are multilevel. They can be analyzed as decisions regarding the manager's own actions (decision maker); decisions regarding its executors (subordinates); decisions regarding the consequences of its implementation (economic, social, psychological, etc.).

At the same time, there is an urgent need for the development of educational technologies that would contribute to the formation of the future specialist's readiness to make and increase the effectiveness of the decisions made, and to acquire them relevant professional competences. As the successful work of the enterprise and the industry, the successful implementation of the project, etc., depend on the decision made, there is an obvious importance of making the right decisions that really lead to the achievement of the set goals. Particularly in the context of active decentralization of power, this refers to the training of management personnel for communities in the embrionical phase.

It should be noted that in the preparation of such a specialist it is important to take into account the fact that the personality of the director-manager is formed and develops precisely during solving certain managerial tasks. Here, harmonious activity, and not just fanaticism of a professional, leads to successful implementation of managerial decisions, when the significance of the result obtained characterizes both the goal and the means of achieving it.

The general analysis of the conditions of decision-making makes it possible to state that a sufficiently high level of self-determination, selforganization, and self-regulation is required from the decision-maker. In our opinion, the crucial thing in resolving this issue is the formation of professional reflection as the most important constructive moment of any thought, the base of professional self-awareness of a specialist manager. Their ability to self-determine in the conditions of rapidly and continuously changing situations, to self-organize in professional and substantive work is ensured thanks to a well-developed reflection. Self-regulation involves not 
simply a willful effort, but a restructuring of semantic formations, the condition of which is their clear awareness ${ }^{7}$.

The professional genesis of the modern manager is stipulated by the constant self-development of his professional reflection, the foundations of which should be laid during his studies at a higher educational institution or during advanced training (retraining).

The training of managers should be oriented to the formation of competencies in order to solve various and different levels of tasks in a particular field of social practice. One can imagine such a hierarchy of these tasks.

Higher level of hierarchy is occupied by common tasks that require the ability to solve them, regardless of profession, qualification or country. Intermediate level - these are specific tasks that are determined by the specific socio-economic and socio-political conditions of a country. The third level covers your own professional tasks ${ }^{8}$. Therefore, not only professional competencies, but also social and personal competences should be formed in the specialist who is preparing by the higher education institution. In our opinion, this aspect of competence is provided by a purposefully organized system of professional thinking formation.

Formation of professional thinking of the manager is manifested primarily in the ability to set goals and solve professional tasks through the use of knowledge and skills acquired in the process of education. An important feature of such thinking is its problematic nature. Difficulty causes and activates not only the processes of thinking, but also the processes of reflection, which are aimed at conscious decision of professionally significant contradictions. That is why understanding the high level of professional thinking of the manager as a process of finding and solving problems, identifying outward-looking properties that transform reality, as well as constructive way out of the ordinary scheme of thinking makes it possible to characterize it as certainly creative and competent ${ }^{9}$.

Preparing directors and managers in the context of the formation of professional thinking requires a progressive movement from existing

7 Максименко С.Д. Розуміння особистості як передумова екологізації життєвого простору. Актуальні проблеми психології: Екологічна психологія : зб.наук.праць Інту психології ім. Г.С. Костюка АПН України / за ред. С.Д. Максименка. Київ, 2003. Т. 7, ч. 1. С. $7-12$.

8 Талызина Н.Ф., Печенюк Н.Г., Хохловский Л.Б. Пути разработки профиля специалиста. Саратов : Изд.дом, 1987. 328 с.

${ }^{9}$ Кашапов М.М. Формирование творческого мышления профессионала как основной вектор инновационных технологий. Ярославский психологический вестник. Ярославль, 2006. Выпуск 18. С. 168-174. 
situational (adaptive) thinking to non-situational (reflective) thinking in relation to different management situations.

Situational thinking is characterized by the dominant influence of life experiences related to current personality orientations. In such circumstances, the problem is not regarded as a certain contradiction, as problematization, but the characteristics of the most available situation are determining. The emphasis of thinking is placed on seeking external help or on known actions in such situations, but introspection and reflection are of random nature. Such thinking is influenced by specific conditions of activity and characterized by the priorities of emotional attitude to the situation in need of solution. Situational thinking is determined by the tendency to make a decision in a moment regarding a situation that arose without preanalysis. This level of thinking is characteristic of a novice specialist who is dominated by adaptive behavior.

The defining task of the entire management training cycle is to create the conditions for mastering a system of reflective (non-situational) thinking, which is ensured by a high level of critical thinking development, the ability to pose problematic questions, the validity of one's professional position and awareness of one's restrictions.

The reflexive refinement of the whole decision-making process highlights the problem of manager's professional training, given that not only subjectprofessional knowledge but also specific means of organizational and managerial work that are indifferent to the subject-professional spheres become important. First and foremost, such means include the reflexive skills of the organizational manager. Therefore, there is a need to develop such skills artificially in the preparation of appropriate personnel.

The specificity of appropriate teaching is that the learner must first acquire a general reflexion experience, and then become aware of it and consolidate it in certain thought-making schemes. This experience in learning situations should be purposefully organized through professional communication. The basis for the organization of such communication can be training and game situations, which are built in a certain way, namely with the obligatory output of reflection. Moreover, to provide training in such situations, there are usually two aspects - emotional and intellectual. In the technical determination of reflection, each of these aspects should be provided with a special type of means. The subject of any activity, in a crisis situation, has at least two options for behavior:

1) complete withdrawal from the activity;

2) output into reflective position in relation to activity.

The first variant arises in a situation where the activity is not significant for the subject, the second variant is associated with a high level of 
significance of the activity situation, the crisis in which creates emotional tension, which initiates the output into reflection. But output into reflection is not a sufficient condition for its realization. The new - reflective - space in which the subject is found must be pronounced in some way, and therefore conscious. Organized verbalization of a new space of professional cooparation will provide another - intellectual - aspect of reflection. The acquisition of skills for transition from an emotional state to an intellectual one is reflexive and provides the decision maker with the psychological means of selforganization. It is a question of self-organization of reflection, of the need not only to work out the means of reflection, but also to reflect the reflection experience itself. That is, during the training of reflection, it is necessary to make a new reflexive "rotation" regarding the experience of reflection.

Therefore, the key to planning the educational process of manager training is the focus on the development of reflective thinking as a condition for achieving a high level of professionalism, the formation of professional thinking. Its formation requires the creation of professional communication environments during training. It is in the course of communication that the need to expand thought in the external plane arises, to structure it in order to be understandable. Here, not organized structures of intellectual activity, meanings, feelings and feels in terms of communication are formulated in one or another sign form. This is due to the fact that the listener, of course, makes certain requirements for the organization of expression. This makes the thought objectified and made available for reflection. It is active communication (professional dialogue, considerable discussion), and subsequently, autocommunication, that changes the form of thought, and thanks to the reflection of its content, provides an individual-semantic context ${ }^{10}$.

Therefore, preparation for professional activity should be ensured by planning such social and educational situations that would enhance creative professional activity and focus on self-development in the profession. The most effective, in our opinion, is the inclusion of managers training forms in the system of training, which would be based on a system-thinking approach.

The basis of the system-thinking approach is the category of activity, and all other phenomena are considered as processes of organization of thinking in activity. Important thing in this approach is the understanding of the concepts of system and systematicity that predetermine functional analysis. The qualitative provision of this approach is the use of basic schemes that organize mental activity in general. The most famous form of development

\footnotetext{
${ }^{10}$ Щедровицкий Г.П. Избранные труды. Москва, 1995. 759 с.
} 
and organization of mentality is organizational and activity game. The complex structural formation of such training forms ensures mastering the techniques of problematizing and designing one's own activity ${ }^{11}$.

The situation of the game, as a specially created educational situation, provides an increase in activity aimed at self-development and actualization of creative professional activity of the learner. The game situation helps to overcome the "fears" associated with the possibility of expressing "wrong" judgments, as well as the identification of problem areas of professional formation, the development of skills of critical attitude to the situation, asserting one's own point of view and taking a reasonable position of another.

The need to include the training forms in managers' preparation of using technologies of organizational and activity games, is based on the position of continuity of the process of professional formation. This technology enables the effective transformation of an adaptive thinking strategy into a strategy of reflective professional thinking. In such classes, the main focus of work with educational recipients is the development of integrated characteristics (orientation, competence, flexibility), which organize the personal component of successful self-realization in the modern world, self-awareness as a specialist, as well as a system of designing their own development strategy.

Educational technologies aimed at forming the professional thinking of the manager in making effective management decisions in social systems require the formation of awareness of social and psychological problems in determining the real subject line of this decision, awareness of the whole system of influences during its implementation. Here a willingness to answer a number of questions should be formed, taking into account the system of subject-subject relations. In its most general form, these are the following basic questions:

- who initiates the decision; who makes the decision; why the decision is made; who is interested in making this decision.

- to whom the decision is directed; what is the attitude to this decision; who will be directly or indirectly affected by this decision.

Consciously answering these questions requires a sufficiently high level of proficiency of both the decision maker and all the participants involved in his/her preparation. That is, the decision not for the person, but for the person as the unconditional basis of the group, organization and society becomes important. Therefore, assessing the optimality of a decision is not only economic indicators, but also the behavior, initiative and activities of people

${ }^{11}$ Дідковський С.В., Красновська Т.М. Досвід застосування організаційно-діяльнісної гри для розвитку молоді. Наукові записки. Сер. : Психологія і педагогіка, 2010. Вип. 14. C. 139-146. URL: http://nbuv.gov.ua/UJRN/Nznuoapp_2010_14_15 
in its adoption and implementation. It can be stated that for the decisionmaker, communicative and auto-communicative processes are a reflection of his/her reflective pattern. Technologically, these patterns are reflected in the constant answer to the question: what needs to be done in specific conditions to achieve the goal; how you can imagine a substantive future; how to get a result that matches the subject form of the result etc.

\section{CONCLUSIONS}

Socio-psychological analysis of the decision-making process at the urban community level should take into account: the most important social indicators, which are integral to its life and reflect its own perception of its subjects as prosperous; the unambiguous perception level of the decision by all subjects with a sense of movement unity towards the goal; the rapidity of change in social situations under the influence of external and internal factors, which today are characterized by a high level of dynamism; features of tracking implementation of decisions at the level of executors; the impact of the decision on the movement and development of the social system, etc.

Effective technological decision-making in social systems at the community level is possible only if the socio-psychological context of this process is consciously monitored. The main components of this analysis are the integral characteristics: the multilevelness of the decision-maker's personal space; a specific manifestation of the decision-maker's responsibility in making the decision; prolonged and ambiguous consequences of the decision implementation.

The analysis of the study results revealed the specific features of organizational forms of social systems and their management entities. Management of an urban community as a formal system is based on the administration of the set stable norms, rules, principles of activity, standards of its subject's behavior, to which we have referred administrative bodies (city authorities), which have formally fixed relevant functions of city management. Management of informal social systems is characterized by the absence of a well-defined set of roles, standards of behavior, variability of interpretations of customs and traditions, spontaneity during direct cooparation, a certain freedom and unpredictability of actions, and the subject of management is fixed functionally in the community opinion. Selforganized social systems are characterized by the dominance of the processes of self-organization, self-government and self-management in relation to socially significant activities in the city, and the subject of management is certain organizations that assume those functions which within their competence cannot be carried out by administrative bodies (initiative groups, public and professional associations, educational institutions, independent societies). 
The research allowed us to highlight three basic management decisionmaking strategies: a strategy for maintaining the life current state of the system; system improvement strategy; a strategy for quality change.

The decision-making process in a social system at the community level is represented by three models of implementation, depending on the relationship between the form of organization of the system and the decision-maker: 1) formal system - city authorities; 2) informal system - reference groups; 3) self-organized system - public organizations.

Distinctive features give us reason to argue that a modern manager is required to possess certain decision-making techniques, and any technological means require consideration of a number of factors that affect the effectiveness of the decision in the context of both its implementation and certain socio-psychological consequences of its decision-making and realization. In our opinion, the basic factors should include awareness of the motivational foundations of decision-making and implementation, the formation of a certain level of self-determination, self-organization, selfregulation, a conscious expert position, as well as, we believe, the formation of reflection experience and development and deepening of professional reflection.

The complexity and multifaceted specificity of decision-making at the urban community level urgently requires the creation of a system of psychological services for organizational effectiveness of these decisions. It is about organizational and social psychologists in the system of self-government of the territorial community, the active involvement of these specialists in forecasting and designing important community decisions.

Given that a managerial decision in social systems has not only economic consequences, it always causes in all subjects to whom it is directed, either positive or negative attitude. That is, it is polyeffective and touches all the meanings: industrial, economic, social, moral and psychological. Therefore, taking into account the psychological aspect of managerial decision-making urgently requires special training of management personnel with the expansion of their socio-psychological knowledge and psychological culture in general. This requires the use of training technologies and organizationalactivity games in the educational process, which enable the use of simulated, dynamic models of generalized options for future professional activity, creating conditions for mastering the system of managerial decision-making from expert positions, which are formed through the developed mechanisms of professional development and mastering certain expert technologies.

Emphasis on mastering the technologies of forming the experience of engaging in reflection of one's own activity during training is a key task of training top-level specialists. Therefore, education in its modern form should 
be presented as a special institution that provides the conditions for transformation of everyday consciousness into those forms that are today in demand of the professional situation and be socially acceptable. The task of transforming values from one (everyday) to another (professional) way is by far the most pressing problem of vocational education.

\section{SUMMARY}

The development of civil society, the creation of non-governmental organisations, the formation of territorial communities, and their unification makes it necessary to determine the specifics of managing social systems that do not have a clear subordination and interaction hierarchy. Our goal is to solve two interrelated tasks: to determine the features of the decision-making process in social systems of different forms of organization (formal, informal, self-organized); distinguishing the specificities of professional training of managers in higher education institutions and the system of retraining to work in the current conditions of global transformation.

The results of the research show that effective technological decisionmaking in social systems at the urban community level is possible only if the social and psychological context of this process is consciously monitored. The main components of this analysis are the integral characteristics: the multilevelness of the personal space of the decision-maker; a specific manifestation of the decision-maker's responsibility in making the decision; prolonged and ambiguous consequences of the implementation of the decision. Analysis of the specific decision-making in social systems revealed three basic strategies for adoption: a strategy to maintain the current state of life of the system; system improvement strategy; a strategy for quality change. During the research we have shown that the decision-making process in the social system at the level of the urban community is represented by three models of implementation, depending on the relationship between the form of organization of the system and the decision-maker: 1) formal system - city authorities; 2) informal system - reference groups; 3 ) self-organized system public organizations. The complexity of decision-making processes requires the creation of a system of psychological services to provide organizational support for community management, the basis of these services should be organizational and social psychologists.

The distinguished specificities of the decision-making process give us reason to state the need for purposeful socio-psychological training of the modern manager. Formation of his/her readiness to become aware of the motivational foundations for making and executing decisions, sufficient level of self-determination, self-organization, self-regulation, conscious expert position, as well as development and deepening of professional 
reflection. Education in its modern form should be presented as a special institute which provides conditions for transformation of everyday consciousness into its forms, which today are in demand of the professional situation and be socially acceptable. The task of transforming values from one (everyday) to another (professional) way is by far the most urgent problem of vocational education.

\section{REFERENCES}

1. Швалб Ю.М. Психологічні засади соціогенеза: громада, населення і спільнота як суб'єкти соціальних відносин. Актуальні проблеми психології : збірник наукових праць. Т. 7. Екологічна психологія, 2014. Вип. 35. С. 317-329. URL: http://www.appsychology.org.ua/data/jrn/v7/ i35/37.pdf

2. Горбань Г.О. Психологія прийнятя управлінських рішень у соціальних системах на рівні міської громади : дис. ... д-ра психол. наук : 19.00.05. Київ, 2014. 493 с.

3. Методы социальной психологии / под общ. ред. Н.С. Минаевой. Москва : Акад. проект ; Екатеринбург : Деловая книга, 2007. 350 с.

4. Горбань Г.О. Соціальні системи як об'єкт управління: соціальнопсихологічний аспект. Актуальні проблеми психології : зб. наук. праць Ін-ту психології ім. Г.С. Костюка НАПН України. Т. I : Організаційна психологія. Соціальна психологія. Економічна психологія / за ред. С.Д. Максименка, Л.М. Карамушки. 2011. Вип. 32 С. 267-272.

5. Горбань Г.О. Психологія прийняття управлінських рішень у соціальних системах на рівні міської громади : Автореф. дис... док. психол. наук: 19.00.05. Київ, 2014. 40 с.

6. Левченко О., Скляр П., Третьяченко В. Соціально-психологічні моделі та механізми професійного становлення майбутніх фахівців у вищій школі : монографія. Луганськ : Вид-во СНУ ім. В. Даля, 2011. 240 c.

7. Максименко С.Д. Розуміння особистості як передумова екологізації життєвого простору. Актуальні проблеми психології: Екологічна психологія : зб.наук.праць Ін-ту психології ім. Г.С. Костюка АПН України / за ред. С.Д. Максименка. Київ, 2003. Т. 7, ч. 1. С. 7012.

8. Талызина Н.Ф., Печенюк Н.Г., Хохловский Л.Б. Пути разработки профиля специалиста. Саратов : Изд.дом, 1987. 328 с.

9. Кашапов М.M. Формирование творческого мышления профессионала как основной вектор инновационных технологий. Ярославский психологический вестник. Ярославль, 2006. Выпуск 18. С. $168-174$.

10. Щедровицкий Г.П. Избранные труды. Москва, 1995. 759 с. 
11. Дідковський С.В., Красновська Т.М. Досвід застосування організаційно-діяльнісної гри для розвитку молоді. Наукові записки. Cep.: Психологія і педагогіка, 2010. Вип. 14. С. 139-146. URL: http://nbuv.gov.ua/UJRN/Nznuoapp_2010_14_15

\section{Information about the author:} Gorban G. O., Doctor of Psychological Sciences, Docent, Professor at the Department of Psychology,

Zaporizhzhia National University 66, Zhukovskoho str., Zaporizhzhia, 69600, Ukraine 